\title{
WHAT IS YOUR DIAGNOSIS? DYSPNOEIC CAT
}

\author{
Erdem Gülersoy ${ }^{1^{*}}$, Mehmet Burak Ateş ${ }^{2}$, Mustafa Yalçin ${ }^{3}$, Süleyman \\ Serhat İyigün ${ }^{4}$, Zeynep Çelik², Burcu Büşra Erol ${ }^{4}$, Hasan Güzelbekteş ${ }^{4}$
}

\author{
${ }^{1}$ Harran University, Faculty of Veterinary Medicine, \\ Department of Internal Medicine, Şanlıurfa, Turkey \\ ${ }^{2}$ Selçuk University, Faculty of Veterinary Medicine, \\ Department of Pathology, Konya, Turkey \\ ${ }^{3}$ Selçuk University, Faculty of Veterinary Medicine, \\ Department of Surgery, Konya, Turkey \\ ${ }^{4}$ Selçuk University, Faculty of Veterinary Medicine, \\ Department of Internal Medicine, Konya, Turkey
}

\section{Abstract}

In this report, a 4-year-old male cat which was brought to Selcuk University, Faculty of Veterinary Medicine, Department of Internal Medicine clinics because of increased dyspnoea, anorexia, weight loss, nasal discharge and excessive salivation over a few days is described. In haemotochemical analysis, leukocytosis, hyperkalaemia, low venous partial pressure and saturation of oxygen level along with azotemia and hypocholesterolemia were determined. For further diagnosis, imaging techniques such as ultrasonography, radiography and computed tomography were performed. While no abnormalities were observed in abdominal ultrasonography, severe left mediastinal shift was detected on radiography; heterogeneous, hypodense areas interpreted as necrotic and granulomatous areas on computed tomography were observed. A diffuse granulomatous pneumonia with severe mediastinal shift was diagnosed based on clinical and laboratory analyses. Humane euthanasia was performed at the request of the owner as cat's general condition started to worsen. The diagnosis was confirmed in the necropsy. In addition, fungal cell walls were observed around the necrotic areas and it was determined that the agent is Cryptococcus. As a result, the diagnostic differentiation and difficulties of dyspnoeic cats were stated through a case of a cat with respiratory distress due to diffuse granulomatous pneumonia

\footnotetext{
${ }^{1 *}$ Corresponding Author: egulersoy@harran.edu.tr
} 
accompanied by necrotic areas and Cryptococcus, and it was concluded that the management protocol which was performed in the present case would be beneficial for clinicians.

Key words: Dyspnea, granulomatous, necrosis, pneumonia, Cryptococcus, diagnostic challenge

\title{
KOJA JE VAŠA DIJAGNOZA? MAČKA SA DISPNEJOM
}

\author{
Erdem Gülersoy ${ }^{1 *}$, Mehmet Burak Ateş ${ }^{2}$, Mustafa Yalçin ${ }^{3}$, Süleyman \\ Serhat İyigün ${ }^{4}$, Zeynep Çelik² ${ }^{2}$ Burcu Büşra Erol ${ }^{4}$, Hasan Güzelbekteş ${ }^{4}$
}

\author{
${ }^{1}$ Univerzitet Harran, Fakultet veterinarske medicine, \\ Departman za internu medicinu, Sanliurfa, Turska \\ ${ }^{2}$ Univerzitet Selcuk, Fakultet veterinarske medicine, \\ Departman za patologiju, Konja, Turska \\ ${ }^{3}$ Univerzitet Selcuk, Fakultet veterinarske medicine, \\ Departman za hirurgiju, Konja, Turska \\ ${ }^{4}$ Univerzitet Selcuk, Fakultet veterinarske medicine, \\ Departman za internu medicinu, Konja, Turska
}

\section{Kratak sadržaj}

U ovom izveštaju opisan se slučaj četvorogodišnjeg mačka koji je donet na kliniku za internu medicinu Fakulteta Veterinarske Medicine Univerziteta Selcuk, zbog pojačane dispneje, gubitka na težini i preterane salivacije koja je trajala nekoliko dana. Hematološkom analizom utvrđena su leukocitoza, hiperkalemija, nizak venski parcijalni pritisak i zasićenost kiseonikom zajedno sa azotemijom i hipoholesterolemijom. Za dalju dijagnozu, sprovedene su tehnike snimanja poput ultrazvuka, radiografije i kompjuterske tomografije. Iako nisu uočene abnormalnosti u ultrazvuku abdomena, na radiografiji je otkriven ozbiljan pomak levog medijastinuma; primećena su heterogena, hipodenska područja interpretirana kao nekrotična i granulomatozna područja na kompjuterizovanoj tomografiji. Na osnovu kliničkih i laboratorijskih analiza dijagnostikovana je difuzna granulomatozna pneumonija sa teškim pomeranjem medijastinuma. Humana eutanazija izvršena je na zahtev vlasnika jer je opšte stanje mačke počelo da se pogoršava. Dijagnoza je potvrđena obdukcijom. Osim toga, uočeni su gljivični ćelijski zidovi 
oko nekrotičnih područja i utvrđeno je da je uzročnik Cryptococcus. Kao rezultat toga, dijagnostička diferencijacija i problemi kod mačaka sa dispnejom prikazane su na slučaju mačke sa respiratornim poremećajem usled difuzne granulomatozne upale pluća praćene nekrotičnim područjima i kriptokokom, te se može zaključiti da bi protokol dijagnostike koji je izveden u ovom slučaju bio koristan kliničarima.

Ključne reči: dispneja, granulomatozna, nekroza, upala pluća, Cryptococcus, izazov u postavljaju dijagnoze

\section{CASE PRESENTATION}

\section{Anamnestic data}

A four-year-old male cat weighing $3.5 \mathrm{~kg}$ was brought with severe lethargy and increasing dyspnoea and respiratory distress, nasal discharge, excessive salivation, loss of appetite and weight loss that were persisting for a few days. It was an indoor cat with access to the outdoors and it was fed homemade diet.

In physical examination, severe laboured abdominal breathing, nasal discharge and excessive salivation were established. Mucous membranes were slightly hyperaemic, with neither jaundice nor cyanosis. There was no jugular distension. Gingival capillary refill time was determined to be 2 seconds. Body temperature was $39.2^{\circ} \mathrm{C}$. During palpation, mildly enlarged mandibular lymph nodes were observed and no abdominal mass was detected. On thoracic auscultation, bronchial crackles in the right lung lobe and dysphonia in the left lobe were noted. The cat was initially stabilised with oxygen therapy (10 liters /minute) by oxygen chamber. Venous blood (jugular venepuncture), urine (mid-stream free-flow) and faecal samples (rectal swab) were taken for laboratory analysis. Abdominal ultrasonography, thoracic and abdominal radiography, and thoracic computed tomography (CT) examinations were performed.

\section{Laboratory Results}

A complete blood count (using a MS4 $\mathrm{e}^{\oplus}$, Melet Schloesing Laboratoires, France), serum biochemistry (using a BT $3000^{\circ}$ plus analyser, Biotecnica Instruments SpA, Rome, Italy), and acid/base, blood gas and electrolyte measurements (using an ABL90 Flex ${ }^{\oplus}$ blood gas analyser, Radiometer Medical ApS, Bronshoj, Denmark) were performed. The results are presented in Tables 1 - 3 respectively. 
Table 1. Haematologic analysis results

\begin{tabular}{lccc}
\hline \multicolumn{1}{c}{ Parameters } & Units & $\begin{array}{c}\text { Tested } \\
\text { Sample }\end{array}$ & $\begin{array}{c}\text { Reference } \\
\text { values }\end{array}$ \\
\hline White cell count & $\mathrm{x} 10^{9} / \mathrm{L}$ & $\mathbf{6 2 . 3}$ & $5.0-19.0$ \\
\hline Granulocytes & $\mathrm{x} 10^{9} / \mathrm{L}$ & $\mathbf{2 4 . 9}$ & $2.0-15.2$ \\
\hline Lymphocytes & $\mathrm{x} 10^{9} / \mathrm{L}$ & $\mathbf{3 7 . 2}$ & $0.2-5.7$ \\
\hline Monocytes & $\mathrm{x} 10^{9} / \mathrm{L}$ & $\mathbf{2 . 2}$ & $0.1-1.1$ \\
\hline Haemoglobin & $\mathrm{g} / \mathrm{dL}$ & $\mathbf{1 6 . 5}$ & $9.5-15.0$ \\
\hline Haematocrit & $\mathrm{L} / \mathrm{L}$ & $\mathbf{0 . 6 4}$ & $0.24-0.45$ \\
\hline Red cell count & $\mathrm{x} 10^{12} / \mathrm{L}$ & $\mathbf{1 3 . 5}$ & $4.0-9.0$ \\
\hline Mean corpuscular volume & $\mathrm{fl}$ & 48 & $35.5-55.0$ \\
\hline Mean corpuscular hemoglobin & $\mathrm{pg}$ & 12 & $16-24$ \\
\hline $\begin{array}{l}\text { Mean corpuscular hemo- } \\
\text { globin concent. }\end{array}$ & $\mathrm{g} / \mathrm{dL}$ & 26 & $28-40$ \\
\hline Red cell distribution width & $\%$ & $\mathbf{1 2 . 7}$ & $8.0-12.0$ \\
\hline Platelets & $\mathrm{x} 10^{9} / \mathrm{L}$ & $\mathbf{2 0}$ & $180-500$ \\
\hline
\end{tabular}

* Includes neutrophils, eosinophils, basophils and mast cells

Table 2. Biochemistry analysis results

\begin{tabular}{lccc}
\hline \multicolumn{1}{c}{ Parameters } & Units & $\begin{array}{c}\text { Tested } \\
\text { sample }\end{array}$ & $\begin{array}{c}\text { Reference } \\
\text { values }\end{array}$ \\
\hline Urea & $\mathrm{mmol} / \mathrm{L}$ & $\mathbf{3 4 . 5}$ & $5.0-12.9$ \\
\hline Creatinine & $\mathrm{mmol} / \mathrm{L}$ & $\mathbf{0 . 4 2}$ & $0.05-0.21$ \\
\hline Aspartate aminotransferase & $\mathrm{U} / \mathrm{L}$ & $\mathbf{1 2 2}$ & $10-100$ \\
\hline Alanine aminotransferase & $\mathrm{U} / \mathrm{L}$ & 94 & $10-100$ \\
\hline Alkaline phosphatase & $\mathrm{U} / \mathrm{L}$ & $\mathbf{1 0 4}$ & $6-102$ \\
\hline Amylase & $\mathrm{U} / \mathrm{L}$ & 668 & $100-1200$ \\
\hline Glucose & $\mathrm{mmol} / \mathrm{L}$ & 8.3 & $3.6-9.4$ \\
\hline Magnesium & $\mathrm{mmol} / \mathrm{L}$ & 0.66 & $0.62-1.03$ \\
\hline Lactate dehydrogenase & $\mathrm{U} / \mathrm{L}$ & 480 & $20-500$ \\
\hline Total bilirubin & $\mathrm{umol} / \mathrm{L}$ & $\mathbf{9}$ & $2-7$ \\
\hline Direct bilirubin & $\mathrm{umol} / \mathrm{L}$ & 3 & $0-7$ \\
\hline Phosphorus & $\mathrm{mmol} / \mathrm{L}$ & 2.1 & $0.8-2.6$ \\
\hline
\end{tabular}




\begin{tabular}{lccc}
\hline \multicolumn{1}{c}{ Parameters } & Units & $\begin{array}{c}\text { Tested } \\
\text { sample }\end{array}$ & $\begin{array}{c}\text { Reference } \\
\text { values }\end{array}$ \\
\hline Cholesterol & $\mathrm{mmol} / \mathrm{L}$ & $\mathbf{1 . 7}$ & $1.9-5.7$ \\
\hline Calcium & $\mathrm{mmol} / \mathrm{L}$ & 2.20 & $2.05-2.69$ \\
\hline Triglycerides & $\mathrm{mmol} / \mathrm{L}$ & 1.7 & $0.3-1.8$ \\
\hline Gamma-glutamyl transferase & $\mathrm{U} / \mathrm{L}$ & 2 & $1-10$ \\
\hline Total Protein & $\mathrm{g} / \mathrm{L}$ & 68 & $52-88$ \\
\hline Albumin & $\mathrm{g} / \mathrm{L}$ & 27 & $25-39$ \\
\hline Creatine kinase & $\mathrm{U} / \mathrm{L}$ & $\mathbf{2 7 7}$ & $10-200$ \\
\hline
\end{tabular}

Table 3. Acid/base, blood gas and electrolyte measurement results

\begin{tabular}{lccc}
\hline \multicolumn{1}{c}{ Parameters } & Units & Tested Sample & $\begin{array}{c}\text { Reference } \\
\text { values }\end{array}$ \\
\hline pH & & $\mathbf{7 . 2 2}$ & $7.35-7.45$ \\
\hline pCO2 & $\mathrm{mm} \mathrm{Hg}$ & $\mathbf{2 7}$ & $40-45$ \\
\hline pO2 & $\mathrm{mm} \mathrm{Hg}$ & 34 & $30-42$ \\
\hline O2 saturation & $\%$ & $\mathbf{5 5}$ & $95-100$ \\
\hline Bicarbonate & $\mathrm{mmol} / \mathrm{L}$ & $\mathbf{1 2 . 7}$ & $19-24$ \\
\hline Base excess & $\mathrm{mmol} / \mathrm{L}$ & $\mathbf{- 1 4 . 8}$ & $-4-4$ \\
\hline Lactate & $\mathrm{mmol} / \mathrm{L}$ & 1.9 & $0-2$ \\
\hline Sodium & $\mathrm{mmol} / \mathrm{L}$ & 164 & $150-165$ \\
\hline Chloride & $\mathrm{mmol} / \mathrm{L}$ & $\mathbf{1 3 5}$ & $104-128$ \\
\hline Potassium & $\mathrm{mmol} / \mathrm{L}$ & $\mathbf{6 . 9}$ & $3.4-5.6$ \\
\hline Calcium & $\mathrm{mmol} / \mathrm{L}$ & $\mathbf{1 . 0 5}$ & $2.0-2.7$ \\
\hline
\end{tabular}

pH: Power of hydrogen; pCO2: Partial pressure of carbon dioxide; pO2: Partial pressure of oxygen; O2: Oxygen

Feline leukaemia virus (FeLV) antigen, feline immunodeficiency virus (FIV) antibody and feline coronavirus (FCoV) antibody tests (ASAN PHARM ${ }^{\circ}$ Co. Ltd, South Korea) were performed according to the manufacturer's instructions and were all negative. Urinalysis using a refractometer revealed specific gravity of 1035. The urine was transparent and dark yellow in colour. Urine dipstick (URIT-31 $1^{\circ}$, India) revealed a $\mathrm{pH}$ of 6.0 , protein $1+$, trace amount of glucose and negative bilirubin and ketones. Microscopic examination of urine 
sediment revealed low numbers of large polygonal squamous cells, occasional erythrocytes and no casts, leukocytes or crystals. The faecal flotation test was negative for common feline endoparasites such as Toxocara cati, Ancylostoma spp., Dipylidium spp., Isospora, and Giardia.

\section{Diagnostic Imaging}

Abdominal ultrasonography revealed no abnormalities in the morphology and echogenicity of the abdominal organs and no effusion was detected. Ventrodorsal and lateral thoracic radiographs are shown in Figure 1. CT was performed using a Toshiba ${ }^{\star}$ Asteion machine (Asteion, Toshiba Medical Systems Corporation, Japan) in helical thoracic scanning mode, using $120 \mathrm{kV}, 100$ $\mathrm{mA}$ and $3 \mathrm{~mm}$ section thickness values. Prior to the CT, the cat was sedated with dexmedetomidine (Domitor ${ }^{ø}$, Zoetis) at $40 \mathrm{mcg} / \mathrm{kg}$ dosage according to the patient's weight. Representative CT images are shown in Figure 2.
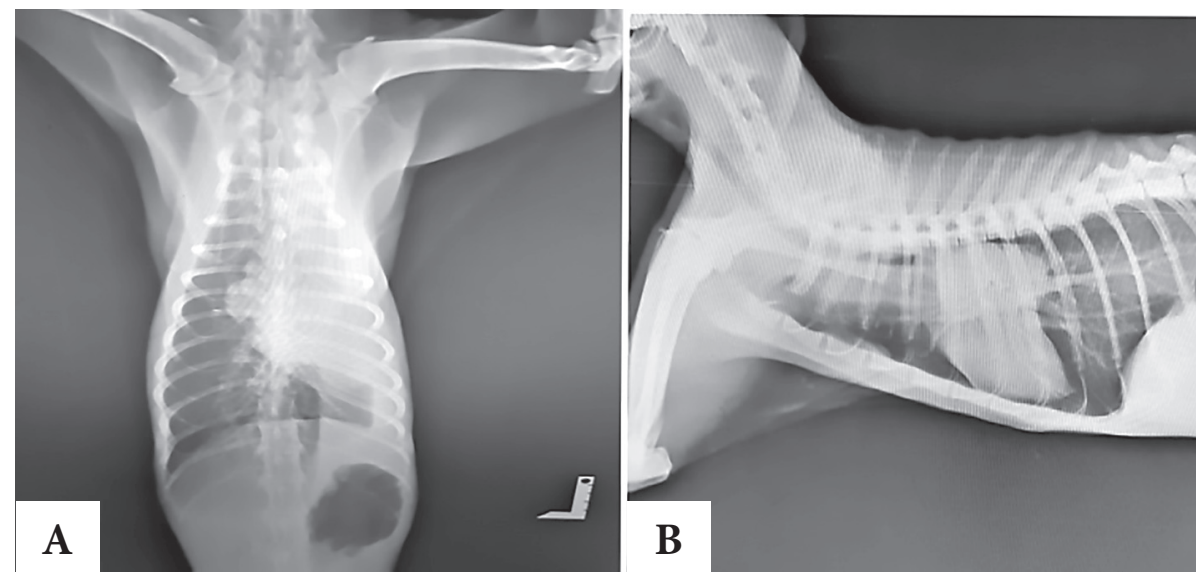

Figure 1. Ventrodorsal and lateral thoracic radiographs of the cat ( $\mathrm{A}$ and $\mathrm{B}$, respectively).

Dyspnoea is a common finding in cats and is often the only symptom of a thoracic disease. A wide variety of conditions such as viral and bacterial diseases, neoplasms, mycotic infections, tracheal diseases such as collapse and stenosis, cardiac diseases and tracheal diseases such as collapse, stenosis were reported to be causative (Blaxter, 1986; Sharp, 2013). After all the above-mentioned information and applied diagnostic tests and methods, the following questions arise: What is your interpretation of these laboratory tests and imag- 
ing results as they relate to this case? What are your differential diagnoses? Are there any further tests that you would perform?
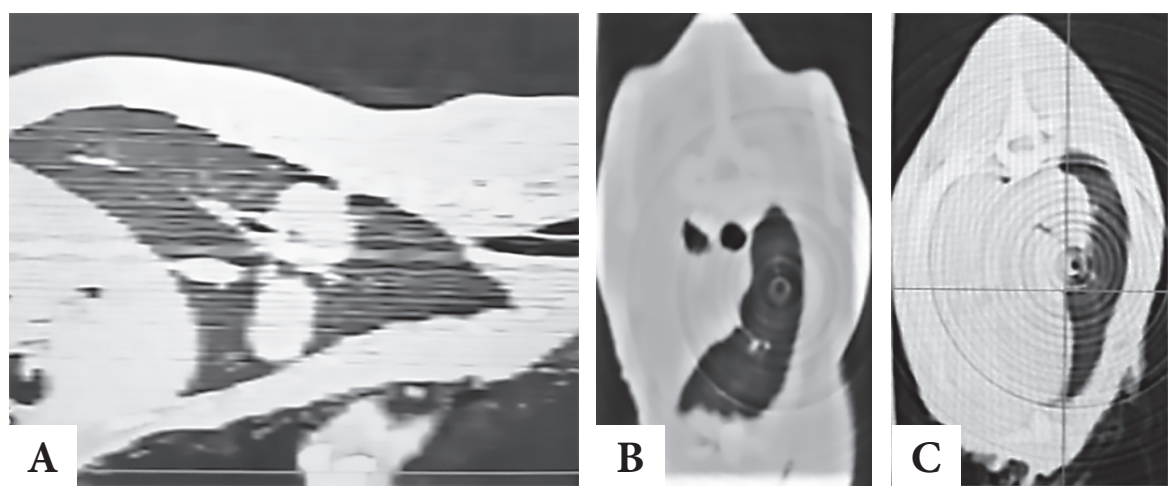

Figure 2. CT images of the cat (A, B and C, respectively)

\section{Clinical Pathology}

Polycythaemia with a moderate to severe prerenal azotaemia was noted. These combined findings support the presence of significant dehydration (Pavelski et al., 2018). In the leukogram, an increase in granulocytes, lymphocytes and monocytes were observed. Further interpretation was required such as assessment of a blood smear in order to determine the types of granulocytes, like whether there was a left-shift and to evaluate cell morphology, especially of the lymphocytes. An inflammatory leukogram was highly likely. Therefore, lymphocytes may reflect antigenic stimulation or lymphoid leukaemia (Wang et al., 2014). Thrombocytopenia in the presented case was the result of clumping of thrombocytes (pseudo thrombocytopenia) which is a common issue in cats and might be secondary to blood sampling technique and handling of peripheral blood (Sumner and Rozanski, 2013). The mild increase in creatine kinase and aspartate aminotransferase were likely the result of muscle ischaemia from dehydration and recumbency, while marginal hypocholesterolaemia was probably due to inanition. The importance of the marginal increases in alkaline phosphatase and total bilirubin were moot (Bart et al., 2000). Acidbase results revealed a marked metabolic acidosis (decreased $\mathrm{pH}$ and bicarbonate concentration and increased base deficit), with secondary respiratory alkalosis (decreased pCO2). The metabolic acidosis explains the hyperkalae- 
mia. It was likely due to dehydration, which also explains the hyperchloraemia (Sumner and Rozanski, 2013). Apart from hypersthenuria, the urinalysis was unremarkable.

\section{Radiographs and CT images}

A severe left mediastinal shift, hyperinflation of the right lung lobe, diffuse infiltration of bronchial tissue and a stomach dilated with gas are shown in Figure 1A (ventrodorsal view). In Figure 1B (left lateral view), a radiopaque tumour-like granulomatous structure in the carina is shown. No cardiomegaly was apparent.

A solitary tumour-like structure (red arrow) with mineralized opacity in the left medial lung lobe and carina and heterogeneous hypodense areas (orange arrows) interpreted as necrotic and granulomatous lesions are shown in Figure 2A. Severe mediastinal shift is apparent in Figure 2B. Total consolidation of left lung lobe is shown in Figure 2C (left lung lobe and heart). No pleural, pericardial, or pulmonary effusions were evident.

\section{Differential diagnoses}

Based on the pulmonary imaging findings, differential diagnoses considered were focal pneumonia, granulomatous lesions, primary or metastatic lung tumors. The most common causes of pneumonia in cats are bacterial. However, fungal, parasitic and viral pneumonia should also be considered (Blaxter, 1986; Cohn, 2009). For further differential diagnosis, it was decided to take bronchoalveolar lavage fluid (BALF) and fine needle aspiration from the affected lung and to prepare the collected sample for culture. Due to the exacerbated respiratory distress in the patient during imaging examinations, the planned further differential diagnostic methods could not be performed and the treatment phase was initiated immediately.

\section{Treatment and Outcome}

The cat was hospitalized and intravenous (IV) fluid therapy (0.9\% isotonic saline, with vitamin-amino acid supplements; Duphalyte ${ }^{\oplus}$, Zoetis, $10 \mathrm{~mL} / \mathrm{kg}$ ), antibiotics (ceftriaxone, $25 \mathrm{mg} / \mathrm{kg} \mathrm{IV}$ ), corticosteroids (prednisolone, $1 \mathrm{mg} / \mathrm{kg}$ IV), nebulization (salbutamol, $100 \mathrm{mcg}$ ) and oxygen therapy (oxygen chamber, $10 \mathrm{~L} / \mathrm{min}$ ) were administered. Despite the treatment, the general condition of the cat did not improve. Humane euthanasia was performed at the re- 
quest of owner after 2 days after admission to the hospital. Cat necropsy was performed.

\section{Pathological Examination}

During the necropsy, multiple grey-white granulomatous foci (approximately $1 \mathrm{~cm}$, between $0.75-1.55 \mathrm{~cm}$ ) on the lungs were observed. The bronchial lymph nodes in the middle of both lung lobes were markedly enlarged (approximately $4.5 \mathrm{~cm}$ ). There was a white-coloured mucopurulent exudate in the trachea and on the left caudal lobe after sectioning. There were large whitish grey areas, which were more severe in the cranial lobe of the right lung, oval-round foci characteristics spreading over large areas in the caudal lobes, without exudate leakage on cross-sectioning. The enlarged lymph nodes were whitish in colour on sectioning with solid consistency. Cardiac examination revealed clotted blood in both ventricles (Figure 3). Although there were minimal and insignificant macroscopic changes in other organs, sampling for histopathology was considered to be useful.

The samples taken from the lung, lymph nodes, heart, brain, intestines, kidney, brain, pancreas and spleen were fixed in $10 \%$ formalin solution for histopathology. Hematoxylin-eosin (HE), periodic acid Schiff (PAS), GrocottGomori's methenamine silver (GMS) and Ziehl-Neelsen (ZN) stains were used (Luna, 1968). The samples of these tissues were sent for microbiology testing.

Diffuse necrosis in the lungs and typical granuloma structures consisting of a small number of lymphocytes, many plasmacytes and epithelioid histiocytes, fibrocytes, fibroblasts and collagen threads around these necrotic foci were determined during routine HE staining of histopathologic examination. In some parts of the lungs, alveolar structures were completely deficient, and were filled with neutrophil leukocytes, alveolar macrophages and shed epithelial cells. Similar findings were observed in the bronchi and bronchioles. In addition, degeneration of bronchial epithelium and severe hyperplasia and desquamation of glands were detected. Thrombus and severe haemorrhagic leaks were noted in the pulmonary vessels. In addition, pale eosinophilic structures with oval-spheroid structure (approximately $20 \mu \mathrm{m}$ ), especially surrounding the necrotic areas in the lung, were observed. 

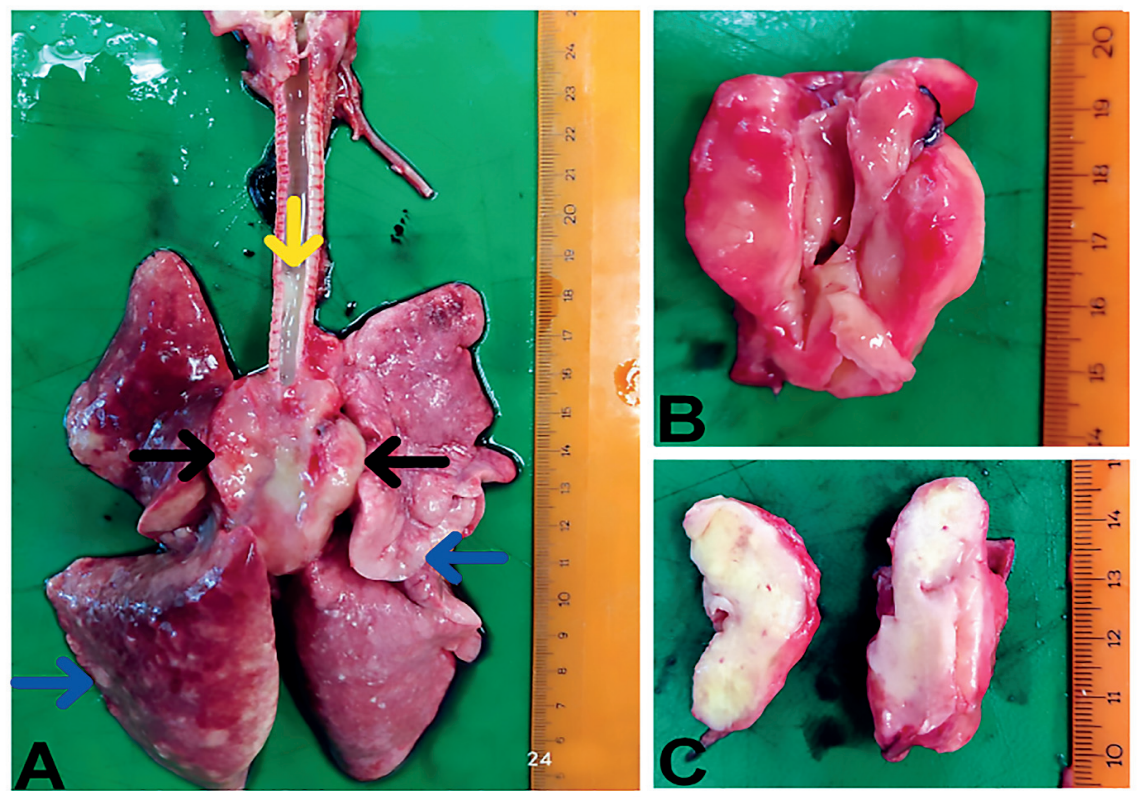

Figure 3. Macroscopic photographs of the lung and bronchial lymph nodes. A: General appearance of the lung, excessively enlarged lymph node between the cranial lobes (black arrow), diffuse gray-white foci in the lung (blue arrow), mucopurulent exudate in the trachea (yellow arrow); B: Extremely enlarged lymph node; C: Sectional face of the lymph nodule.

These structures were determined to be positive using PAS and GMS staining. No acid-resistance bacteria were found in the ZN staining. Granulomatous lesions were observed both in the affected lymph nodes and in the lungs. Degeneration and desquamation in the tubular epithelium of the kidneys, protein-rich fluid in the lumen, plasmahistiocytic cell infiltration in the interstitium and an increase in the fibrous tissue were detected. Congestion in the liver, atrophy of hepatocytes and compensation hypertrophy of the vena centralis were observed. In addition to the increase in the connective tissue of the pancreas, degeneration and desquamation were observed in the duct epithelium (Figure 4). It was reported that no bacterial agent could be isolated in microbiological analyses (48 hours, routine set of culture media was MacConkey agar as the tissue materials were mostly purulent). 

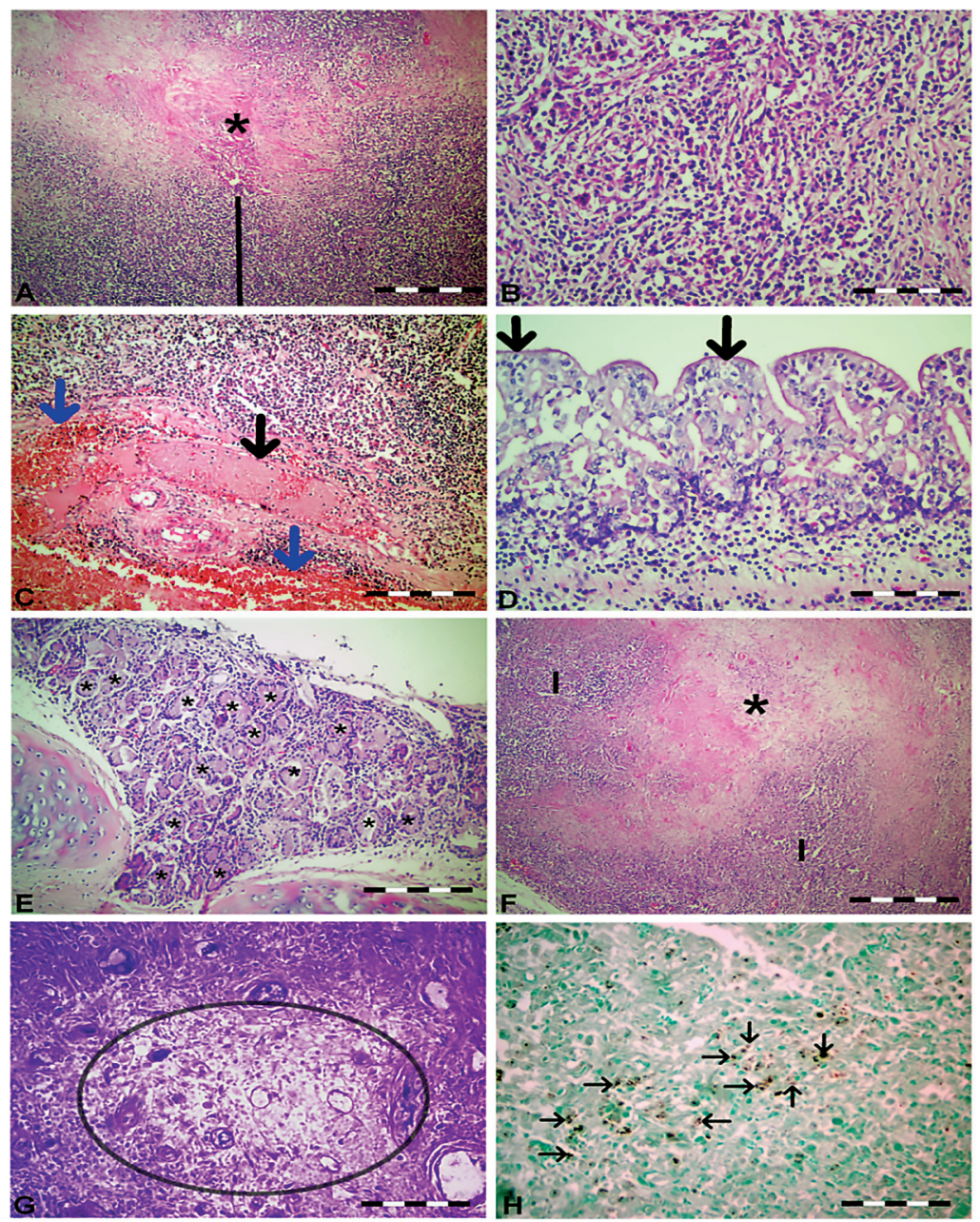

Figure 4. A: Granulomatous pneumonia, typical granuloma structure, necrosis (asterisk) in the middle and the surrounding inflammatory cell line (line), HE, Lung, Scale bar: $200 \mu \mathrm{m}$; B: Inflammatory and connective tissue cells forming the granuloma, HE, Lung, Scale bar: $50 \mu \mathrm{m}$; C: Thrombosis in vein (black arrow) and bleeding (blue arrow), HE, Lung, Scale bar: $100 \mu \mathrm{m}$; D: Degeneration in bronchial epithelium (black arrow), HE, Lung, Scale bar: $50 \mu \mathrm{m}$; E: Severe hyperplasia and desquamation in the bronchial glands (asterisk), HE, Lung, Scale bar: $100 \mu \mathrm{m}, \mathrm{F}$ : Granulomatous lymphadenitis, necrosis in the middle (asterisk) and the surrounding inflammatory cell line (line), HE, lymph node, Scale bar: $200 \mu \mathrm{m}$; G: Pale eosinophilic fungal (Cryptococcosis) structures with oval-spheroid structure around the necrosis areas in the lung, PAS, Lung, Scale bar: $100 \mu \mathrm{m}$; H: Many positively stained fungal agents, GMS stain, Lung, Scale bar: $100 \mu \mathrm{m}$. 


\section{DISCUSSION}

In the present case, a definitive diagnosis of a diffuse granulomatous pneumonia with severe mediastinal shift caused by pulmonary Cryptococcosis was established based on clinical, laboratory and necropsy findings.

The first approach of dyspnoeic cats is to determine the localization of the lesion in the respiratory tract, lung lobe or pleural space and to make differential diagnosis on the basis of the patient's anamnesis, signalment, physical, laboratory and imaging findings. Since the mediastinum is in contact with the facial surfaces of the neck and retroperitoneal space, pneumomediastinum, diaphragmatic hernia, pleural effusion, atelectasis and masses can be detected in the presence of mediastinal shift (Blaxter, 1986; Cohn 2009). Although the exact etiology of this pathological condition is unclear in many cases, it is known to be highly correlated with viral infections such as feline leukaemia and feline immunodeficiency virus (Newman and Schaible, 2019). Studies have reported that fixed shift of mediastinum is associated with mass lesions such as scoliosis, pneumonectomy, atelectasis, pleural operations, effusion or granulomatous structures (Pavelski et al., 2018). In our case, histopathological examination confirmed that mediastinal shift detected in radiographic examination was associated with diffuse granulomatous lesions.

As stated by various researchers (Bart et al., 2000; Cohn, 2009), radiographic examination is one of the most useful diagnostic tools in cats with respiratory distress and should be done with caution in dyspnoeic cats. Lateral and dorsoventral or ventrodorsal imaging is essential for complete evaluation (Elsmo et al., 2018). Radiopaque areas were seen in the left thoracic region on ventrodorsal radiological examination. Radiopaque granulomatous appearance in the mediastinal and carina regions was noted on lateral radiography. Although the use of CT in feline thorax has been rarely described, feline CT anatomy has been reported by Samii et al. (1998). In the present case, unilateral lymph node enlargement and mediastinum invasion were detected in the CT examination. In addition, patterns with different opacity as a result of air loss in the lungs were detected. Hypodense areas refer to necrotic debris. With CT imaging of feline thorax, differential diagnosis of granulomatous lesions, pulmonary abscesses, primary lung tumours, metastatic lung tumours, pneumonia, congenital or parasitic cysts can develop. Necrotic areas in granulomatous lesions are generally observed in a heterogeneous structure on CT images (Foster and Martin, 2011). The structures interpreted in the CT image of our case are the following: thoracic spine, ribs, sternum, muscular thoracic wall, pleural space and diaphragm, respectively. Subsequently, the mediastinum was 
evaluated along with the trachea, oesophagus, thymus and the heart. Finally, bronchi and lungs were examined. As a result, heterogeneous necrotic areas were detected within diffuse granulomatous lesions with severe mediastinal shift. With this systematic examination, not only was the obvious pathological condition determined, but the changes that could affect the treatment and prognosis were also observed. In addition to bacterial, viral, fungal and parasitic pneumonia and bronchopneumonia, allergic and idiopathic inflammatory changes in the lung are often manifested as marked changes in density and different distribution patterns of the alveolar space. Specific CT findings of different inflammatory lung diseases have not yet been established in dogs and cats, but some general characteristics have been identified. CT findings often show a tendency to soft tissue opacification, which is evident in fungal pneumonia, and associated perihilar lymphadenopathy (Roden and Schuetz, 2017). In the present case, the lesions detected by CT imaging are similar to the reported findings of fungal pneumonia.

Feline necrotic pneumonia has been reported before (Sharp, 2013). Although cats and dogs with necrohemorrhagic pneumonia associated with extraintestinal Escherichia coli and Bartonella henselae (Sharp, 2013; Sumner and Rozanski, 2013) are generally evaluated as subclinical, various clinicopathological abnormalities such as anaemia, fever, neurological dysfunction, endocarditis and pyelogranulomatous myocarditis and diaphragmatic myositis may be evident. In addition, Elsmo et al. (2018) reported that necrotic interstitial pneumonia and suppurative myocarditis developed due to $B$. henselae infection in their study on three Florida pumas, diffuse tracheal haemorrhage, thoracic effusion, lung colour change, pulmonary edema, and duodenal haemorrhage and lymphadenomegaly developed in necropsy findings. They also reported that the most important microscopic finding was acute, fibrinonecrotic, and haemorrhagic interstitial pneumonia. In the present case, alveolar collapse with mediastinal shift, diffuse granulomatous structures and surrounding necrotic areas, severe haemorrhage in the lung parenchyma, mucopurulent leakage in the respiratory tract were detected in the necropsy, and the diagnosis of diffuse granulomatous pneumonia with mediastinal shift was confirmed. In addition, fungal agents were observed with GMS and PAS staining of spheroid structures around the necrotic areas.

Fungal infections are generally characterized by granulomatous or pyogranulamatous pneumonia (Sumner and Rozanski, 2013). The lungs are considered the primary site for human Cryptococcal infection. Although pulmonary Cryptococcal infections have rarely been reported in cats, pulmonary lesions were reported in $29 \%$ of cats with radiographic abnormalities and $38 \%$ 
in necropsy in a previous study (Sura et al., 2007). In the lung histopathology of pulmonary Cryptococcus infection, pathogens can be detected within the transparent areas that are not stained around the necrotic lung tissue. These pathogens appear as an oval fungal organism of various sizes, with a shell-like blue-grey or red staining. The necrotic area surrounded by many macrophages with vacuoles and also fibrosis with minor lymphocyte infiltration may be seen. It was reported that in the necrotic areas, with PAS staining eosinophilic, with GMS staining brown-black stained fungal cell walls can be seen (Vogl et al., 2015). In the present case, the histopathological examination findings of necrotic areas in the lung tissue were consistent with the findings of previously reported Cryptococcal infections. Roden and Schuetz (2017) reported that this type of infections may be accompanied by necrotized or non-necrotized granulomas. In some cases, the organism may not be detected in GMS or PAS staining and, in these cases, polymerase chain reaction (PCR) or fungal serology can be performed from tissue samples. Lack of BALF sampling, PCR analysis, or fungal serology are the limitations of this clinical report.

Dyspnoeic cats are usually cause emotional distress to their owners. Minimizing patient stress is very important and it can be difficult to apply the appropriate diagnostics to decide the best treatment protocol for the patient. A composed, logical approach that involves clinical observation, laboratory analysis, thoracic radiography and ultrasonography, CT and, where necessary, echocardiographic examinations are vital. In most cases, the protocol that was followed in our case is sufficient - applying empirical treatment, achieving successful stabilization and retrenching the list of diseases to be considered in differential diagnosis.

In this clinical report, the diagnosis of diffuse granulomatous pneumonia, which was established after imaging techniques were performed following by non-specific clinical and laboratory findings, was confirmed in histopathological examination and it was found that it was complicated with fungal pneumonia as a result of positive GMS and PAS staining. The histopathological findings were consistent with Cryptoccocosis infection. No bacteria were detected in the culture of tissue samples. Although a systemic examination protocol is important for a successful diagnosis and treatment in dyspnoeic cats, this is very difficult for clinicians. In this presented manuscript, the diagnostic difficulty of dyspnoeic cats was stated over a cat case with respiratory distress due to diffuse granulomatous pneumonia accompanied by necrotic areas and complicated with Cryptoccocosis infection. It was concluded that the management protocol which was followed in the present case would be useful for the differential diagnosis and management of dyspnoea in cats for clinicians. 


\section{Author's Contribution:}

E.G. performed the ultrasonographic examinations and together with H.G., interpreted the haemotochemical results and wrote the manuscript; M.Y. performed radiographic and computed tomography examinations; M.B.A. and Z.Y. performed necropsy and did histopathologic examinations; B.B.E. and S.S.İ. did the examination and collection of the data of the cat; the final version of the manuscript was drafted by E.G. with the assistance of all coauthors who revised the manuscript.

\section{Competing interest}

The authors declare that they have no competing interests for a work presented in the manuscript.

\section{REFERENCES}

1. Bart M., Guscetti F., Zurbriggen A., Pospischil A., Schiller I. 2000. Feline infectious pneumonia: a short literature review and a retrospective immunohistological study on the involvement of Chlamydia spp. and distemper virus. Veterinary Journal, 159, 220-230. doi:10.1053/tvjl.1999.0451.

2. Blaxter A. 1986. Differential diagnosis of dyspnoea in the cat. In Practice, 8, 225-227. doi:10.1136/inpract.8.6.225.

3. Cohn, L.A. 2009. Pulmonary parenchymal disease. In. Textbook of Veterinary Internal Medicine. Eds. Ettinger S., and Feldman E., Elsevier, Saunders, St. Louis, USA, 7th edition, eBook ISBN: 9781437702828.

4. Elsmo E.J., Fenton H., Cleveland C.A., Shock B., Cunningham M., Howerth E.W., Yabsley M.J. 2018. Necrotizing interstitial pneumonia and suppurative myocarditis associated with Bartonella henselae infection in three Florida pumas. Journal of Veterinary Diagnostic Investigation, 30, 728732. doi:10.1177/1040638718789226.

5. Foster S. and Martin P. 2011. Lower Respiratory Tract Infections In Cats Reaching beyond empirical therapy. Journal of Feline Medicine and Surgery, 13, 313-332. doi:10.1016/j.jfms.2011.03.009.

6. Luna, L.G. 1968. Manual of histologic staining methods of the Armed Forces Institute of Pathology. Blakiston Division, McGraw-Hill, New York, 3rd edition.

7. Newman R. and Schaible M. 2019. Isolation of Cryptococcus gattii from feline chronic stage lipoid pneumonia. Medical Mycology Case Reports, 25, 19-21. doi:10.1016/j.mmcr.2019.06.002. 
8. Pavelski M., Seixas S.V., Warth J.F.G., de Souza C., Dittrich R.L., Froes T.R. 2018. Fungal pneumonia in dogs and cats with pulmonary clinical signs in southern Brazil. Pesquisa Veterinaria Brasileira, 38, 696-702. doi:10.1590/1678-5150-PVB-5066.

9. Roden A.C. and Schuetz A.N. 2017. Histopathology of fungal diseases of the lung. Seminars in Diagnostic Pathology, 34, 530-549. doi:10.1053/j. semdp.2017.06.002.

10. Samii V.F, Biller D.S., Koblik P.D. 1998. Normal cross-sectional anatomy of the feline thorax and abdomen: comparison of computed tomography and cadaver anatomy. Veterinary Radiology and Ultrasound, 39, 504-511. doi:10.1111/j.1740-8261.1998.tb01640.x.

11. Sharp C.R. 2013. Feline lower airway disease: Presentation and diagnosis. Today's Veterinary Practice, 20, 3, 28-31. Available at: https://todaysveterinarypractice.com/diagnosis-of-feline-lower-airway-disease/ Accessed 01.08.2021.

12. Sumner C. and Rozanski E. 2013. Management of Respiratory Emergencies in Small Animals. Veterinary Clinics of North America - Small Animal Practice, 43, 799-815. doi:10.1016/j.cvsm.2013.03.005.

13. Sura R., Van Kruiningen H.J., DebRoy C., Hinckley L.S., Greenberg K.J., Gordon Z., French R.A. 2007. Extraintestinal pathogenic Escherichia coliinduced acute necrotizing pneumonia in cats. Zoonoses Public Health, 54, 307-313. doi:10.1111/j.1863-2378.2007.01067.x.

14. Vogl T.J., Reith W., Rummeny E.J. (Eds.) 2015. Chest and Mediastinum. Diagnostic and Interventional Radiology, 12, 479-587. Springer-Verlag, Berlin, Heidelberg, 2016. doi:10.1007/978-3-662-44037-7_19

15. Wang J., Zhou Q., Cai H., Zhuang Y., Zhang Y., Xin X., Meng F., Wang Y. 2014. Clinicopathological features of pulmonary cryptococcosis with cryptococcal titan cells: a comparative analysis of 27 cases. International Journal of Clinical and Experimental Pathology, 7, 4837-4846. PMID: 25197354.

Received: 26.06.2021. Accepted: 09.08.2021. 